\title{
BREEDING DISTRIBUTION OF BIRD SPECIES IN HANNAH POINT - LIVINGSTON ISLAND, ARCHIPELAGO OF SOUTH SHETLANDS, ANTARCTICA
}

\author{
Maria Virginia Petry*, Gabriela Bandasz Werle \& Gustavo Aver \\ Laboratório de Ornitologia e Animais Marinhos, Universidade do Vale do Rio dos Sinos - UNISINOS, \\ Av. Unisinos, 950, Cristo Rei, São Leopoldo, CEP 93022-00, Rio Grande do Sul, RS, Brazil \\ *e-mail:vpetry@unisinos.br \\ https://doi.org/10.4322/apa.2016.007
}

\begin{abstract}
Environmental changes are responsible for alterations in ecological and biological organisms, affecting their phenology, distribution, physiology, cycles, composition, and interactions with communities, as well as the structure and dynamics of ecosystems. This study aims to perform the mapping of breeding sites and distribution of breeding birds in Hannah Point, Livingston Island, and assess the abundance of reproductive pairs for each of these species. The areas occupied by nesting birds were georeferenced with the assistance of a GPS receiver and the number of breeding pairs was established by the mean of the scores obtained by three observers. The distribution of breeding groups of these birds was represented on a map. Nine species of birds were observed breeding in Hannah Point, namely, Pygoscelis antarcticus, Pygoscelis papua, Eudyptes chrysolophus, Macronectes giganteus, Daption capense, Phalacrocorax atriceps, Chionis albus, Stercorarius lonnbergi, and Larus dominicanus.
\end{abstract}

Keywords: Abundance, Seabirds, Reproductive Pairs, Phenology

\section{Introduction}

Environmental changes are responsible for impacts on the phenology of organisms living in seasonal environments (Beebee, 1995; Crick et al., 1997). In addition, other ecological and biological consequences resulting from such changes affect the distribution, physiology, cycles, composition, and interactions with communities of species, as well as the structure and dynamics of ecosystems (Walther et al., 2002). The Polar Regions comprise areas where signs of climate change are stronger, especially the Antarctic Continent, where there has been an increase in temperature with melting of glaciers (Murphy et al., 1995; Smith et al., 1999; Vaughan et al., 2001).

Birds that breed in Antarctica are extremely sensitive to the observed climate variations. Changes in the reproductive timing (late arrival to the fields of reproduction with consequent late oviposition) of some of these bird species were reported by Barbraud \& Weimerskirch (2006). Performing the mapping of reproduction areas and monitoring the breeding groups, evaluating the consequences of climate variations on these species, are highly relevant actions to detect possible influences of these changes on these populations. This study aims to perform the mapping of reproduction and distribution areas for the birds that breed in Hannah Point and quantify the abundance of each species.

\section{Materials and Methods}

The present study was conducted in Hannah Point (62'39'10"S; 54³6’30"W), on Livingston Island, during the austral summer of 2012, in December. Points of breeding birds that reproduce on the site were georeferenced with the support of a GPS receiver. Subsequently, the data collected were processed using the ArcGIS software program to draw a map with the distribution and breeding areas for each species. To conduct the census of species, three observers simultaneously performed the direct counting, of the number of nests in order to establish the number of breeding pairs and the number of individuals in each reproductive 

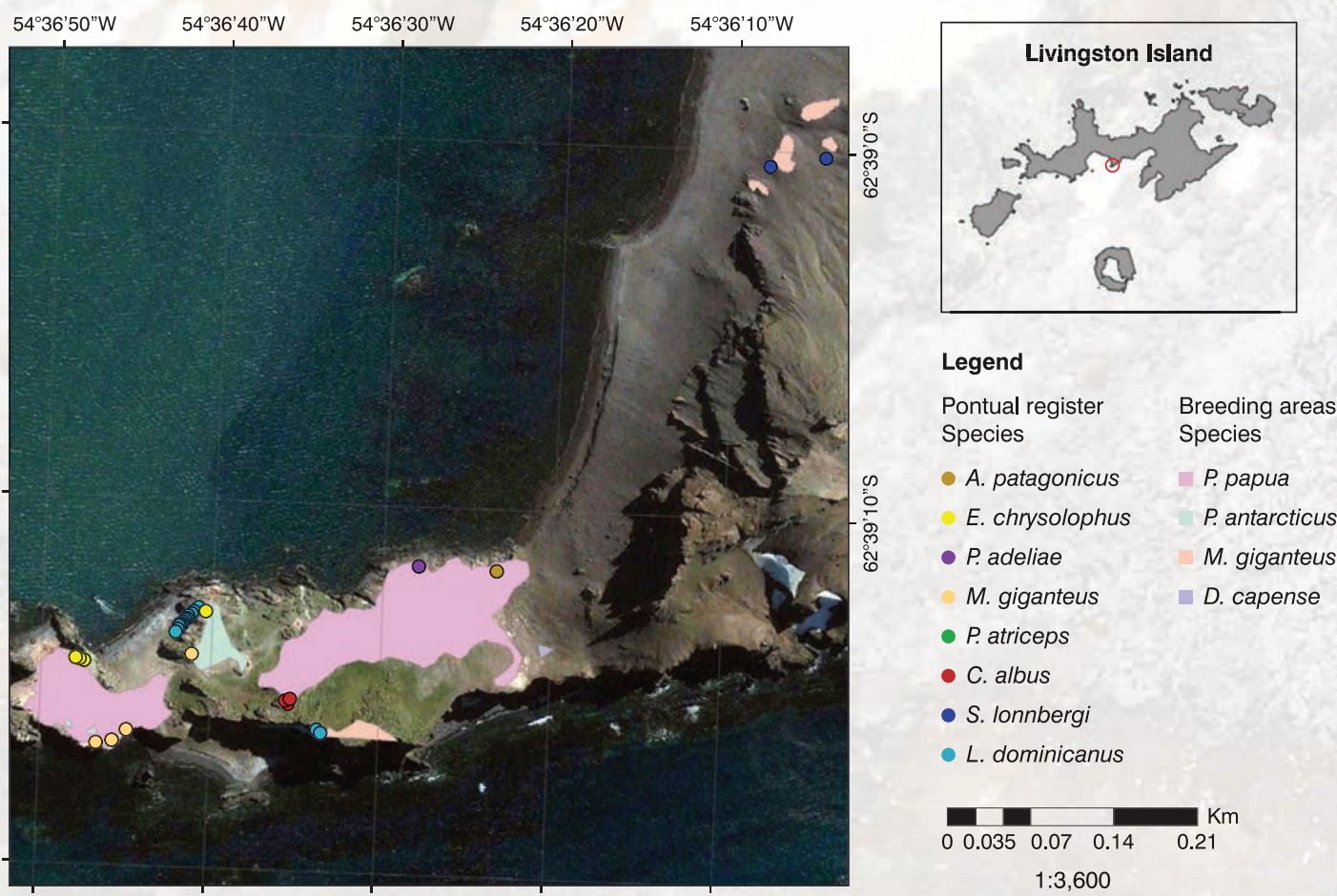

Figure 1. Map of breeding areas and individuals found in Hannah Point in the reproductive season of 2012 (Source: Base of Hannah Point: Google Earth Pro).

Antarctic birds. The area was completely free of snow, enabling reproduction of the nine aforementioned species in December 2012, as well as the appearance of a wider microhabitat range that contributes to the establishment of a larger number of species (Volkman \& Trivelpiece, 1981; Rönkä et al., 2008). The P. papua species occupied a larger area because these individuals showed improved tolerance of nesting places with different slopes. P. antarticus showed greater occupation of areas without inclination, resulting in a decrease in the area used by this species.

The giant petrels occupied mostly higher plateaus, as these individuals prefer rugged environments to start flying (Mehlum et al., 1988). Other three species nested in steep areas near the sea: $D$. capense, with small breeding groups; P. atriceps, which build nests on slopes of different rates of inclination, facing the sea; and $L$. dominicanus, which prefer the edges of higher cliffs. Similar behavior to occupy the ice-free areas during the austral summer was also observed by Punta et al. (2003). Weidinger (1996a, 1996b) reported that $D$. capense usually build nests on rocky cliffs facing the sea, at altitudes above $45 \mathrm{~m}$; therefore, this species occupied the smallest area among species that formed colonies in the study area.

It is worth noting that, among the species recorded occasionally, a nest of E. chrysolophus was found near the breeding area of $P$. antarcticus. In turn, King Penguins and Adelie Penguins were observed resting in the area, corroborating information from other studies that reported the presence of non-breeding individuals in other regions of Antarctica (Heezik et al., 1994; Petry et al., 2013). The mapping of marine breeding birds allows us to assess temporal changes in these areas and, therefore, verify how environmental variables may be influencing these species (Rönkä et al., 2008).

The mapping of these breeding areas allows us to analyze the relationship between these bird species and the environmental conditions during the breeding seasons. However, these mapping must be related to the information of basic ecology of these individuals, as well as to the climatic conditions that may influence their reproduction. Further studies to measure the abundance and map the distribution of these birds are required so that bird populations that dwell 


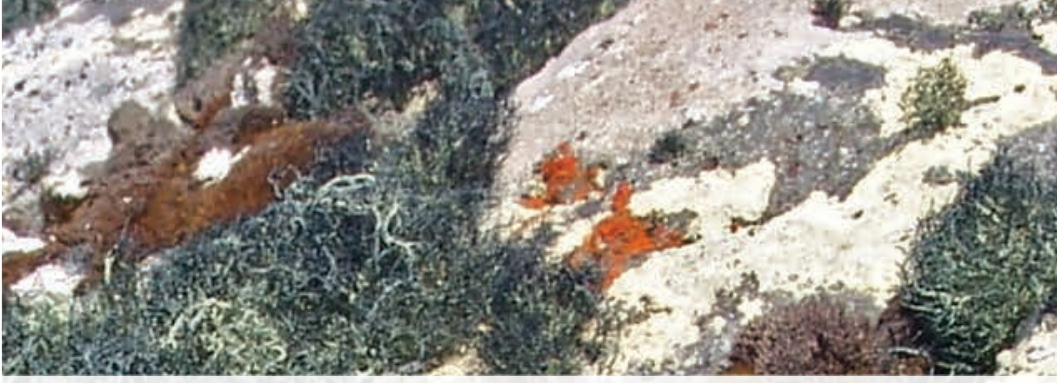

and nest in Hannah point can be continuously monitored and possible threats can be detected.

\section{Acknowledgements}

This work integrates the National Institute of Science and Technology Antarctic Environmental Research (INCTAPA) that receives scientific and financial support from the
National Council for Research and Development (CNPq process: no. 574018/2008-5) and Carlos Chagas Research Support Foundation of the State of Rio de Janeiro (FAPERJ no. E-16/170.023/2008). The authors also acknowledge the support of the Brazilian Ministries of Science, Technology and Innovation (MCTI), Environment (MMA), and InterMinistry Commission for Sea Resources (CIRM).

\section{References}

Barbraud, C., \& Weimerskirch, H. (2006). Antarctic birds breed later in response to climate change. Proceedings of the National Academy of Sciences of the United States of America, 103(16), 6248-6251.

Beebee, T. J. C. (1995). Amphibian Breeding and Climate. Nature, 374, 219-220.

Crick, H. Q. P., Dudley, C., Glue, D. E., \& Thomson, D. L. (1997). UK birds are laying eggs earlier. Nature, 388, 526.

Heezik, Y. V., Seddon, P. J., Cooper, J., \& Plös, A. L. (1994). Interrelationships between breeding frequency, timing and outcome in King Penguins Aptenodytes patagonicus: are King Penguins biennial breeders? The Ibis, 136(3), 279-284.

Mehlum, F., Gjessing, Y., Haftorn, S., \& Bech, C. (1988). Census of breeding Antartic Petrels Thalassoica antartica and physical features of the breeding colony at Svarthamaren, Dronning Maud Land, with notes on breeding Snow Petrels Pagodroma nivea and South Polar Skuas Catharacta maccormick. Polar Research, 6, 1-9.

Murphy, E. J., Clarke, A., \& Symon, C. (1995). Temporal variation inAntarctic sea-ice: analysis of a long term fast-ice record fromthe South Orkney Islands. Deep-sea Research. Part I, Oceanographic Research Papers, 42, 1045-1062.

Petry, M. V., Basler, A. B., Valls, F. C. L., \& Krüger, L. (2013). New southerly breeding location of king penguins (Aptenodytes patagonicus) on Elephant Island (Maritime Antarctic). Polar Biology, 36(4), 603-606.

Punta, G., Yorio, P., Saravia, J. R., \& Borboroglu, P. G. (2003). Breeding habitat requirements of the Imperial Cormorant and Rock Shag in Central Patagonia, Argentina. Waterbirds, 26, 176-181.

Rönkä, M., Tolvanen, H., Lehikoinen, E., Numers, M., \& Rautkari, M. (2008). Breeding habitat preferences of 15 bird species on South-western Finnish archipelago coast: applicability of digital spatial data archives to habitat assessment. Biological Conservation, 141, 402-416.

Smith, R. C., Ainley, D., Baker, K., Domack, E., Esmlie, S., Fraser, B., Kennett, J., Leventer, A., Mosley-Thompson, E. Stammerjhon, S., \& Vernet, M. (1999). Marine ecosystem sensitivity to climate change. Bioscience, 49, 393-404.

The Commission for the Conservation of Antarctic Marine Living Resources - CCAMLR. (2004). Retrieved from www.ccamlr.org

Vaughan, D. G., Marshall, G. J., \& Connelly, W. M. (2001). Perspectives: climate change: devil in the detail. Science, 293, 1777-1779.

Volkman, N. J., \& Trivelpiece, W. (1981). Nest-site selection among adélie, chinstrap and gentoo penguins in mixed species rookeries. The Wilson Bulletin, 93, 243-248.

Walther, G. R., Post, E., Convey, P., Menzel, A., Parmesan, C., Beebee, T. J. C., Fromentin, J. M., Hoegh-Guldberg, O., \& Bairlein, F. (2002). Ecological responses to recent climate change. Nature, 416, 389-395.

Weidinger, K. (1996a). Egg variability and hatching success in the Cape petrel Daption capense at Nelson Island, South Shetland Islands, Antarctica. Journal of Zoology, 239, 755-768

Weidinger, K. (1996b). Patterns of colony attendance in the Cape Petrel Daption capense at Nelson Island, South Shetland Islands, Antarctica. The Ibis, 738, 243-249. 